\title{
PENGELOLAAN BENGKEL TEKNIK MEKATRONIKA DI SMK
}

\author{
Eko Mulyanto \\ SMK Negeri 2 Sukoharjo \\ mas_eko_76@yahoo.co.id
}

\begin{abstract}
The purpose of this study is (1). Describe the procurement of equipment and materials in the workshop practices Mechatronics SMK Negeri 2 Sukoharjo. (2). Describing the use of tools and materials in the workshop practices Mechatronics SMK Negeri 2 Sukoharjo. (3). Describe Maintenance of tools and materials in the workshop practices Mechatronics SMK Negeri 2 Sukoharjo. The research was conducted at SMK Negeri 2 Sukoharjo. This type of research is qualitative research with a naturalistic approach. The technique of collecting data through observation, interviews and documentation. The study design using the design ethnography. The informant as a resource is the principal, vice-principal fields of infrastructure, head of engineering packages mechatronics and mechatronic engineering practice teacher. The collected data was then analyzed by means of data reduction, presentation / display data and drawing conclusions / verification. Testing the validity of using, triangulation source and triangulation techniques. Research result are showing that the procurement of equipment and materials may gradually be met by the school. The Central Government provides financial assistance, in the form of deconcentration fund is realized through the proposal and verification proposal. The use of mechatronic engineering workshop solely for practical learning process to improve students'skills. Program activities in mechatronic engineering workshop include the provision, use and maintenance of tools and materials. Based on the findings of this research for the procurement of mechatronic engineering workshop equipment is good, need to conduct equipment maintenance technicians and are designed to be held periodically or periodic maintenance. Similarly, for an inventory of equipment and materials showed the results have not oftimal due to the lack of space for storage of tools and materials.
\end{abstract}

Keywords: management, procurement, use and maintenance materials

\begin{abstract}
ABSTRAK
Tujuan penelitian ini adalah (1).Mendeskripsikan pengadaan alat dan bahan praktik di bengkel Teknik Mekatronika SMK Negeri 2 Sukoharjo. (2). Mendeskripsikan Penggunaan alat dan bahan praktik di bengkel Teknik Mekatronika SMK Negeri 2 Sukoharjo. (3). Mendeskripsikan Pemeliharaan alat dan bahan praktik di bengkel Teknik Mekatronika SMK Negeri 2 Sukoharjo. Penelitian dilakukan di SMK Negeri 2 Sukoharjo. Jenis penelitian yang adalah penelitian kualitatif dengan pendekatan naturalistik. Teknik pengumpulan data dengan observasi, wawancara dan
\end{abstract}


dokumentasi. Desain penelitian menggunakan desain etnografi. Informan sebagai nara sumber adalah kepala sekolah, wakil kepala sekolah bidang sarana prasarana, kepala paket keahlian teknik mekatronika dan guru praktik teknik mekatronika. Data yang telah terkumpul selanjutnya dianalisis dengan cara reduksi data, penyajian/ display data dan penarikan kesimpulan/verifikasi. Pengujian keabsahan mengunakan triangulasi sumber dan triangulasi teknik. Hasil penelitaian ini adalah menunjukan bahwa pengadaan peralatan dan bahan secara bertahap dapat dipenuhi oleh sekolah. Pemerintah pusat memberikan bantuan dana, berupa dana dekonsentrasi yang direalisasi melalui proposal dan verifikasi proposal. Penggunaan bengkel teknik mekatronika semata- mata untuk proses pembelajaran praktikum untuk meningkatkan keterampilan siswa. Program kegiatan dalam bengkel teknik mekatronika meliputi pengadaan, penggunaan dan pemeliharaan alat dan bahan. Berdasarkan hasil temuan penelitian ini untuk pengadaan peralatan bengkel teknik mekatronika sudah baik, perlu mengadakan teknisi pemeliharaan peralatan dan dirancang untuk diadakan perawatan periodik atau berkala. Demikian pula untuk inventarisasi peralatan dan bahan menunjukan hasil belum optimal dikarenakan belum adanya ruang untuk penyimpanan alat dan bahan.

Kata kunci: pengelolaan, pengadaan, penggunaan dan pemeliharaan alat bahan

\section{PENDAHULUAN}

Sekolah Menengah Kejuruan (SMK) Negeri 2 Sukoharjo merupakan sekolah kejuruan yang memiliki 7 jenis paket keahlian, yang kini tengah diminati oleh masyarakat dimana setiap tahunnya mengalami peningkatan jumlah pendaftar (lampiran 3). Paket keahlian yang dimiliki oleh SMK Negeri 2 Sukoharjo meliputi Paket Keahlian: Teknik Gambar Bangunan, Teknik Pemeliharaan Mesin Industri, Teknik Mekatronika, Teknik Kendaraan Ringan, Teknik Kimia Industri, Agribisnis Ternak Ruminansia dan Teknik Pengeloaan Hasil Pertanian. Untuk mencapai tujuan itu SMK Negeri 2 Sukoharjo terus berupaya untuk memperbaiki kualitas dan mutu pendidikannya, dengan membuat program-program pengembangan sekolah sesuai dengan kriteria yang telah ditetapkan.

Sarana dan prasarana praktik mempunyai peranan yang sangat penting keberadaannya dalam pendidikan di Sekolah Menengah Kejuruan (SMK) khususnya selain sumber daya manusia itu sendiri. Dengan sarana dan prasarana yang lengkap didukung dengan sumber daya manusia yang berkualitas akan memberikan hasil pendidikan yang baik pula.

Tersedianya sarana dan prasaran praktik dimaksudkan agar dapat memenuhi standar pelayanan ataun Standart Operational Procedur (SOP) dalam sebuah bengkel kerja. Terkait dengan hal tersebut, tentu saja tidak lepas dari segi pembiayaan yang tidak sedikit. Maka perlu diberlakukanya sistem pengalokasian dan pengelolaan yang professional, yang bertujuan agar pembiayaan dapat digunakan secara efektif dan efisien. Sehingga perkembangan hasil belajar siswa secara individu dan berkesinambungan dapat terpantau. .

Dalam Undang-Undang Nomor 20 Tahun 2003 tentang Sistem Pendidikan Nasional disebutkan, pendidikan nasional berfungsi mengembangkan kemampuan dan membentuk 
watak peradaban bangsa yang bermartabat dalam rangka mencerdaskan kehidupan bangsa dan meningkatkan sumber daya manusia. Pendidikan bertujuan mengembangkan potensi peserta didik agar menjadi manusia yang beriman dan bertaqwa kepada Tuhan Yang Maha Esa, berakhlak mulia, sehat, berilmu, cakap, kreatif, mandiri, dan menjadi warga negara yang demokratis serta bertanggung jawab.

Undang-Undang Sistem Pendidikan Nasional menyebutkan pendidikan menengah kejuruan merupakan pendidikan yang mempersiapkan peserta didik untuk dapat bekerja dalam bidang tertentu. Sedangkan menurut PP nomor 19 tahun 2005 tentang Standar Nasional Pendidikan (SNP) disebutkan pendidikan menengah kejuruan adalah jenjang pendidikan menengah yang mengutamakan pengembangan kemampuan siswa untuk jenis pekerjaan tertentu. Kebijakan yang dibuat oleh pemerintah, dalam hal ini Kementerian Pendidikan Nasional dimaksudkan untuk meningkatkan mutu pendidikan khususnya Sekolah Menengah Kejuruan (SMK) di Indonesia.

Sekolah merupakan suatu komunitas belajar yang mengembangkan potensi atau kemampuan siswa. Proses pendidikan terarah dan terencana pada penguasaan pengetahuan, kemampuan, ketrampilan, pengembangan sikap dan nilai-nilai dalam rangka pembentukan dan pengembangan diri siswa. Yang pada gilirannya semua itu akan diperlukan untuk berbagai kepentingan.

Saat ini SMK baik status negeri maupun swasta sudah banyak yang menerapkan Sistem Manajemen Mutu (SMM) ISO 9001: 2008. Diterapkannya standar internasional ini agar SMK lebih baik dalam pengelolaannya dan terstandar. Standarisasi pelayanan ini diterapkan pada seluruh unit kerja yang ada termasuk unit kerja bengkel. Bengkel dengan kelengkapannya harus dikelola dengan baik agar selalu siap digunakan praktikum siswa.

Bengkel merupakan tempat untuk melakukan kegiatan siswa dalam peningkatan ketrampilan. Di bengkel siswa dapat meneliti, mengidentifikasi, menganalisa, merawat dan memperbaiki hal-hal yang ada kaitannya dengan kompetensinya. Dalam kegiatan praktikum siswa dapat menerapkan teori yang didapat di kelas kemudian mengaplikasikannya di bengkel. Pembelajaran di bengkel dilakukan dengan pendekatan ketrampilan proses. Untuk itu peran bengkel menjadi sangat penting karena bengkel merupakan pusat proses belajar mengajar di Sekolah Menengah Kejuruan (SMK).

Paket Keahlian Teknik Mekatronika SMK Negeri 2 Sukoharjo mempuyai bengkel diantaranya 1). laboratorium /bengkel Teknik Kontrol yang didalamnya Elektropneumatik, Pneumatik, Elektromagnetik, 2). Bengkel Programmer, PLC, micro digunakan untuk praktik Programmable Logic Control, Microkontroler, 3). Bengkel Elektronika Dasar untuk praktik dasar - dasar mekatronika, yang ketiga bengkel tersebut menjadi tempat latihan bagi siswa untuk meningkatkan keterampilan di bidang Mekatronika. Fasilitas bengkel/laboratorium dilengkapi dengan peralatan yang mengikuti peralatan di perusahaan atau industri, hal ini untuk memberi dukungan kepada siswa untuk menyerap materi, berinovasi, dan meningkatkan ketrampilan sesuai dengan perkembangan yang di industri atau perusahaan.

\section{METODE}

Strategi pendekatan atau jenis penelitian menggunakan penelitian kualitatif dengan pendekatan naturalistic. Menurut (Sutama , 2015 : 64) karakteristik penelitian naturalistik 
yaitu: Penelitian bekerja dalam konteks natural / alamiah, menggunakan manusia sebagai instrumen penelitian, memanfaatkan pengetahuan implisit ( tersirat ),memanfaatkan sampel purposif (sengaja/dengan pertimbangan), memanfaatkan metode analisis data induktif, .

penelitian naturalistik ceenderung membuat kesepakatan bersama dan lebih menyukai modus laporan studi kasus, penelitian naturalistik memilih penyusunan desain sementara dan menuju ke teori dasar. Desain dalam penelitian ini adalah etnografi, dimana peneliti terjun langsung sebagai subjek, sekaligus mengamati peristiwa yang sebenarnya terjadi dilapangan.

Teknik pengumpulan data yang digunakan dalam penelitian ini observasi, wawancara, dan dokumentasi. Observasi (Observation) yaitu pengamatan terhadap suatu objek yang diteliti secara langsung yaitu dengan terjun langsung terlibat di lapangan saat pengambilan data dan secara tidak langsung yaitu pengamatan yang dibantu dengan media visual/audiovisual misal handpone, kamera, handycam dan lain-lain yang semua itu untuk memperoleh data yang harus dikumpulkan peneliti. (Satori dan Komariah, 2014 : 105).

Wawancara (interview) yaitu dengan melakukan interaksi komunikasi atau percakapan antara pewawancara (interviewer) dan terwawancara (interviewee) yaitu informan yang daripadanya pengetahuan dan pemahaman diperoleh dengan maksud menghimpun data/ informasi dari informan tersebut. (Satori Djam'an dan Komariah Aan, 2014 : 129).

Dokumentasi (Documentation), cara ini digunakan untuk memperoleh data/dokumen berupa catatankejadian yang sudah lampau yang dinyatakan dalam bentuk lisan, tulisan maupun karya bentuk. (Satori Djam'an dan Komariah Aan, 2014 : 148).

Menurut Satori dan Komariah (2014 : 168). Agar data yang telah dianalisis dapat dipertanggungjawabkan kebenaran dan keabsahannya, maka usaha yang dilakukan peneliti adalah dengan cara trianggulasi atau pengecekan data dari berbagai sumber dengan berbagai cara dan waktu.

Trianggulasi Sumber, yaitu dengan mencari data dari sumber yang beragam yang masih terkait satu sama lain. Hal ini peneliti perlu melakukan eksplorasi/menggali data untuk memperoleh kebenaran data dari berbagai sumber yaitu Kepala sekolah, Wakil Kepala Sekolag bidang Sarana Prasara, Kepala Paket Keahlian dan Guru Teknik Mekatronika. Trianggulasi Teknik, yaitu menggunakan beragam teknik pengungkapan data yang dilakukan kepada sumber data, menguji kredibilitas/kepercayaan data dengan sumber yang sama tetapi teknik yang berbeda yaitu dengan wawancara, observasi maupun dokumentasi. Trianggulasi Waktu, yaitu untuk mengecek konsistensi, kedalaman dan ketepatan/kebenaran suatu data. Cara yang dilakukan dengan mengumpulkan data pada waktu yang berbeda.

Analisis data ini bertujuan untuk mencari dan data secara sistematis dari hasil rekaman atau catatan observasi, wawancara dan dokumentasi yang telah dilakukan. Proses analisis data dalam penelitian ini mengadopsi pemikiran Miles dan Huberman (dalam Satori dan Komariah, 2014 : 218) proses analisis data yaitu proses pengumpulan data, reduksi data, penyajian/display data, dan penarikan kesimpulan. 


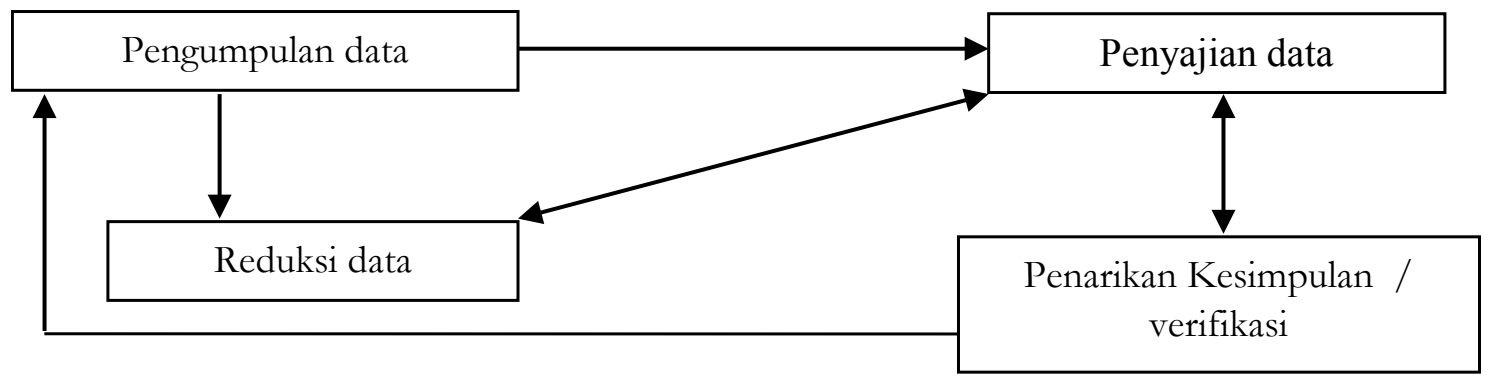

Gambar 1. Interactive Model

(Satori dan Komariah, $2014: 218$ )

Langkah analisis data dapat diuraikan (1). Reduksi Data/ Reduction, data yang beragam bentuk/jenis dan banyak dari peneliti, perlu dianalisis melalui reduksi data. Data yang diperoleh ditulis dalam bentuk laporan atau data yang terperinci, lalu dirangkum dan dipilih hal-hal yang pokok serta difokuskan pada hal yang penting saja sehingga diperoleh data yang akurat. (2). Penyajian data/ Data Display, setelah data direduksi peneliti, selanjutnya menyajikan data (display) dalam bentuk seperti tabel, teks naratif dan sejenisnya dengan format yang sistematik. Memudahkan dalam memahami data, juga untuk merencanakan kegiatan selanjutnya berdasarkan hasil dari reduksi data tersebut. (3). Penarikan kesimpulan/ verifikasi, kesimpulan /verifikasi merupakan temuan baru yang sebelumnya belum pernah ada, yang dapat berupa deskripsi atau gambaran yang sebelumnya belum jelas sehingga setelah diteliti menjadi jelas, dapat berupa hubungan kausal atau interaktif, hipotesis maupun teori.

\section{HASIL DAN PEMBAHASAN}

Temuan peneliti mengenai Pengelolaan Bengkel Teknik Mekatronika di SMK Negeri 2 Sukoharjo adalah sebagai berikut:

1. Pengadaan alat dan bahan praktik.

Pengadaan alat dan bahan dimulai dari proses perencanaan dimana dalam proses perencanaan diawali pembuatan analisis kebutuhan alat dan bahan praktik yang diajukan oleh masing-masing guru mata pelajaran produktif/praktik dengan melihat kebutuhan alat dan bahan yang terdapat dalam pada Rencana Program Pembelajaran (RPP) dari setiap guru mata pelajaran produktif serta setiap guru harus membuat Rencana Anggaran Biaya (RAB) alat dan bahan praktik dari setiap mata pelajaran yang diampunya. Setelah itu kepala paket keahlian Teknik Mekatronika menyeleksi kebutuhan alat dan bahan sesuai skala prioritas mana yang penting untuk diadakan terlebih dahulu. Setelah itu hasil dari seleki alat dan bahan yang dilakukan Kepala Paket Keahlian Teknik Mekatronika bersama Kepala Bengkel di ajukan ke Wakil Kepala Sekolah bidang sarana prasarana. Apabila dari wakil kepala sekolah bidang sarana prasarana sudah menyetujui maka kepala sekolah memberikan petunjuk dan memberikan tugas kepada wakil kepala sekolah bidang sarana dan prasana sebagai koordinator, yang dibantu oleh Kepala Tata Usaha, Kepala paket keahlian dan kepada guru yang sudah mempunyai sertifikat pengadaan barang untuk membeli atau mengadakan alat dan bahan sesuai dengan usulan yang ada. Untuk rekanan atau toko yang dijadikan tempat membeli harus dengan syarat, untuk pembelian barang atau alat dan bahan dengan rekanan yang sudah 
ditunjuk sekolah minimal 3 rekanan atau toko sebagai pembanding, dengan membeli di toko yang paling murah dari ketiga toko tersebut tetapi dengan kualitas sama atau harganya lebih mahal tetapi kualitasnya lebih baik dan tiap toko tersebut mempunyai NPWP (Nomor Pokok Wajib Pajak).

2. Penggunaan alat dan bahan praktik.

Dalam hal penggunaan alat dan bahan praktik di bengkel Teknik Mekatronika SMK Negeri 2 Sukoharjo, dimulai dengan proses peminjaman alat atau dengan kartu bon / kartu pinjam alat dan bahan. Kartu pinjam alat tersebut wajib ditulis alat dan bahan yang akan digunakan dan di tanda tangani peminjam dan disetujui oleh Kepala Bengkel, bila kepala bengkel tidak ada dapat diketahui oleh guru pengampu praktik, dengan tujuan pengunaan alat dan bahan akan terpantau dengan baik sehingga jika terdapat alat yang rusak akan segera terdeteksi dan jika bahan habis juga akan mudah proses pengadaannya kembali. Untuk inventarisasi peralatan ada petugas khusus dari sekolah yang dibantu oleh kepala paket keahlian serta kepala bengkel bertugas secara umum mengecek keberadaan alat dan bahan di bengkel Teknik Mekatronika. Kegiatan yang dilakukan dalam inventarisasi alat dan bahan secara berkala atau periodik, mendata dan mengecek ulang alat dan bahan yang sudah tersalurkan di bengkel Teknik Mekatronika, tentang keberlakuan dan kegunaan dari alat dan bahan tersebut. Apabila ada alat yang tidak bisa di perbaiki di bengkel Teknik Mekatronika maka alat tersebut dicatat dalm berita acara dan di serahkan ke wakil kepala sekolah bidang sarana prasarana untuk diperbaiki di instansi lain.

\section{Pemeliharaan alat dan bahan praktik.}

Keterlibatan pemeliharaan alat dan bahan di bengkel Teknik Mekatronika, sebagai penanggung jawab adalah kepala keahlian Teknik Mekatronika. Namun dalam pelaksanaannya di bantu oleh kepala bengkel, guru produktif dan juga melibatkan siswa. Mengapa melibatkan siswa, tujuannya adalah supaya siswa merasa memiliki yang akhirnya dapat memelihara dan menggunakan dengan penuh tanggung jawab baik sesuai dengan petunjuk penggunaan alat dan bahan. Prosedur pemeliharaan alat dilaksanakan secara berkala, setiap alat dipasangi kartu perawatan alat, sehingga setiap alat yang akan digunakan dan setelah digunakan tercatat di kartu pemeliharaan alat. Apabila terjadi kerusakan pada alat dicatat dalam kartu pemeliharaan alat, namun apabila ada alat yang rusak dan tidak dapat diperbaiki oleh petugas yang di bengkel maka akan di serahkan ke wakil kepala sekolah bidang sarana prasarana untuk di perbaiki di instansi luar. Untuk kebijakan dalam pemeliharaaan alat, diharapkan dalam pemakaian alat diharapkan sesuai prosedurnya supaya tahan lama, bahkan bila siswa merusakkan alat secara fatal harus bertanggung jawab supaya mengganti agar yang lainnya tidak sembrono dalam menggunakan alat, dan dari sekolah sendiri juga ada dana pemeliharaan alat dan bahan.

Pembahasan dapat dilaksanakan apabila temuan dari penelitian sudah dirumuskan, pembahasan penelitian ini berkaitan dengan " Pengelolaan Bengkel Teknik Mekatronika SMK Negeri 2 Sukoharjo”, setelah itu akan dirumuskan dalam bentuk teori-teori atau hasil penelitian. Dan didukung oleh data penelitian dan penelitian-penelitian terdahulu, sehingga hakikat dari penelitian ini akan mudah dipahami maknanya. 


\section{Pengadaan alat dan bahan di bengkel Teknik Mekatronika SMK Negeri 2 Sukoharjo.}

Berdasarkan hasil temuan penelitian menunjukkan bahwa proses pengadaan alat bahan di bengkel Teknik Mekatronika SMK Negeri 2 Sukoharjo sudah memenuhi aturan yang ada, dengan cara membeli alat dan bahan dimulai dari perencanaan yang berisi usulan pengajuan alat dan bahan yang diajukan oleh guru-guru di jurusan Teknik Mekatronika pada saat awal pembelajaran tahun ajaran baru. Karena itu dilaksanakan analisis kebutuhan alat bahan dan seleksi peralatan, dengan mempertimbangkan pula skala prioritas dari alat dan bahan yang akan diadakan. Hasil temuan penelitian ini sesuai dengan Permendiknas no.17 tahun 2007 tentang standar pengelolaan pendidikan bidang sarana dan prasana : Program pengelolaan sarana dan prasarana mengacu pada Standar Sarana dan Prasarana dalam hal : 1).merencanakan, memenuhi dan mendaya gunakan sarana dan prasarana pendidikan; 2). mengevaluasi dan melakukan pemeliharaan sarana dan prasarana agar tetap berfungsi mendukung proses pendidikan; 3). melengkapi fasilitas pembelajaran pada setiap tingkat kelas di sekolah/ madrasah; 4). menyusun skala prioritas pengembangan fasi-litas pendidikan sesuai dengan tujuan pendidikan dan kurikulum masing-masing tingkat; 5). pemeliharaan semua fasilitas fisik dan peralatan dengan memperhatikan kesehatan dan keamanan lingkungan.

Hasil temuan penelitian ini juga sesuai dengan penelitian Purwanto dan Sukardi (2015), yang menyatakan bahwa perencanaan, pengorganisasian, pelaksanaan dan pengawasan mempunyai kualitas baik akan berdampak baik pada pengelolaan bengkel. Hasil temuan penelitian ini juga sesuai dengan penelitian Ramadina dan Hadi (2015), menyatakan bahwa pengembangan sistem informasi manajemen bengkel kerja Sekolah Menengah Kejuruan dalam memberikan pelayanan sistem informasi manajemen bengkel sekolah yaitu dengan analisis kebutuhan dan penilaian produk. Hasil temuan penelitian ini juga sesuai dengan penelitian Odden and Wohlstetter (1995), menyatakan bahwa apabila kita ingin mendirikan sekolah kejuruan yang baik maka di dasari dengan pengelolaan/ manajemen bengkel yang baik pula.Juga sesuai dengan penelitian Pahlevi, Imron dan Kusumaningrum (2016), menyatakan bahwa manajemen sarana dan prasarana dapat meningkatkan mutu pembelajaran dengan perencanaan sarana dan prasarana yang dimulai dari analisis kebutuhan yang dilakukan oleh kepala paket keahlian kemudian diajukan kepada Waka Sarpras. Hasil temuan penelitian ini juga sesuai dengan penelitian Darmastuti dan Karwanto (2014), menyatakan bahwa pengadaan, perencanaan sarana dan prasarana dilakukan dengan tujuan mengetahui semua kebutuhan sarana dan prasarana sekoah, harus direncanakan di awal tahun dengan melihat hasil evaluasi pada tahun sebelumnya, pendistribusian sarana dan prasarana dilakukan dengan cara menyeleksi sesuai kebutuhan, selanjutnya barang yang dibeli kemudian disalurkan kepada tiap program jurusan atau bengkel.

Dari hasil pernyataan-pernyataan dan hasil temuan penelitian terdahulu tersebut terdapat beberapa kesamaan dan saling mendukung diantaranya adalah adanya analisi kebutuhan alat sebelum pengadaan alat dan bahan tersebut, adanya seleksi kebutuhan alat, penyaluran atau pendistribusian alat ke tiap paket keahlian. Oleh sebab itu maka pada pengadaan alat dan bahan praktik di bengkel Teknik Mekatronika SMK Negeri 2 Sukoharjo dilakukan untuk pemenuhan praktik siswa walaupun secara bertahap, sesuai dengan analis kebutuhan dan pengajuan alat dari masing-masing guru serta melihat skala prioritas kebutuhan alat dan bahan. 


\section{Penggunaan alat dan bahan di bengkel Teknik Mekatronika SMK Negeri 2 Sukoharjo}

Berdasarkan hasil temuan penelitian menunjukkan bahwa penggunaan alat dan bahan di mulai dengan proses pemasangan kartu perawatan alat, setelah itu adanya pengajuan kartu pinjam atau kartu bon alat dan bahan oleh siswa yang diketahui oleh kepala bengkel. Prosedur penggunaan dari masing-masing alat harus sesuai dengan Standart Operational Procedur(SOP) dan semua alat harus diinventaris untuk mengetahui keadaan dan kegunaannya. Penggunaan alat dan bahan diatur oleh kepala paket keahlian sesuai jadwal pelajaran praktik/produktif, sehingga tidak benturan dengan pelajaran yang lain. Selanjutnya untuk inventarisasi alat dan bahan di bengkel Teknik Mekatronika ada petugas khusus di bawah kendali wakil kepala sekolah bidang sarana prasarana, namun dalam pelaksanaan di bengkel atau jurusan Teknik Mekatronika di bantu oleh kepala paket keahlian dan kepala bengkel. Kegiatan dalam inventarisasi alat dan bahan yaitu secara berkala mendata dan mengecek ulang keberadaan serta kegunaan dari alat dan bahan tersebut, sehingga semua alat dan bahan akan tercatat di buku inventaris jurusan maupun sekolah.

Hasil temuan penelitian ini juga sesuai dengan penelitian Andriani, Yudana, dan Natajaya (2015), yang menyatakan bahwa identifikasi dan analisis kendala dalam manajemen pengelolaan bengkel (laboratorium) dapat memenuhi standar apabila dikelola dengan baik, didukung dengan peralatan sudah terinvetaris dengan baik dan pemakaian peralatan juga terpantau dengan kartu perawatan alat. Hasil temuan penelitian ini juga sesuai dengan penelitian Gusbantoro, Hano dan Sutama (2015), yang menyatakan bahwa pengelolaan bengkel kerja, dimulai dengan perencanaan alat sesuai analisis kebutuhan alat dan bahan, inventarisasi dilakukan dengan mencatat alat ke dalam buku inventaris. Pengadaan dilakukan dengan membeli dan menerima bantuan, pemeliharaan sesuai dengan ukuran waktu dan keadaan barang. Hasil temuan penelitian ini juga sesuai dengan penelitian Riswanti, Samani, dan Palupi (2015), yang menyatakan bahwa pengaruh pengelolaan bengkel terhadap pengetahuan, ketrampilan praktik dan motivasi belajar siswa, dapat mempengaruhi peningkatan hasil pengetahuan, keterampilan praktik dan motivasi belajar siswa. Hasil temuan penelitian ini juga sesuai dengan penelitian Haron, Esmon, Yaacob, dan Abas (2014), menyatakan pengelolaan bengkel yang melibatkan guru-guru di Malaysia memegang peranan penting dalam mendukung effektivas belajar mengajar.

Dari pernyataan narasumber dan hasil penelitian tentang penggunaan peralatan dalam bengkel terdapat kesamaan pendapat yaitu terdapatnya jadwal penggunaan laboratorium, tersedianya kartu perawatan alat, adanya kartu bon/pinjam alat serta invebtarisasi alat, maka penggunaan alat dan bahan di bengkel Teknik Mekatronika harus berpedoman pada prosedur sehingga penggunaan alat dan bahan akan lebih effektif.

\section{Pemeliharaan alat dan bahan praktik}

Pemeliharaan alat dan bahan praktik di bengkel Teknik Mekatronika SMK Negeri 2 Sukoharjo, secara umum menjadi tanggung jawab kepala paket keahlian Teknik Mekatronika. Namun dalam pelaksanaannya dibantu oleh kepala bengkel juga siswa pada saat setelah praktik. Pemeliharaan dilakukan secara berkala dengan cara setiap alat atau trainer terdapat kartu perawatan, sehingga peralatan yang sudah digunakan diperiksa kartu perawatannya 
apakah sudah di isi belum mengenai kondisi alat baik sebelum dan sesudah praktik. Hasil temuan penelitian ini juga sesuai dengan Peraturan Pemerintah Republik Indonesia Nomor 19 Tahun 2005 Tentang Standar Nasional Pendidikan, Pasal 42 : “ Setiap satuan pendidikan wajib memiliki sarana yang meliputi perabot, peralatan pendidikan, media pendidikan, buku dan sumber belajar lainnya, bahan habis pakai, serta perlengkapan lain yang diperlukan untuk menunjang proses pembelajaran yang teratur dan berkelanjutan.” Dan juga pada Pasal 47,“ Pemeliharaan sarana dan prasarana pendidikan sebagaimana dimaksud dalam Pasal 42 sampai dengan Pasal 46 menjadi tanggung jawab satuan pendidikan yang bersangkutan. Pemeliharaan sebagaimana dimaksud pada ayat (1) dilakukan secara berkala dan berkesinambungan dengan memperhatikan masa pakai."

Hasil temuan penelitian ini juga sesuai dengan penelitian Audu, Umar, dan Idris (2013), yang menyatakan bahwa pelaksanaan kurikulum pendidikan di Nigeria untuk mendukung efektifitas pengajaran dan pembelajaran dapat dicapai apabila terdapat pengadaaan dan pemeliharaan tempat atau fasilitas yang memadai. Hasil temuan penelitian ini juga sesuai dengan penelitian Rufai, Musta'amal, Kamin, dan Saud (2013), yang menyatakan bahwa untuk mencapai effektivitas pengelolaan bengkel kerja, maka proses pengawasan terhadap peralatan praktek sangat penting dilakukan, hal ini menjadi tanggung jawab guru dan petugas bengkel dengan melakukan pengecekan dan pemeliharaan barang, kondisi dan kelengkapan barang. Hasil temuan penelitian ini juga sesuai dengan penelitian Sudiarta, Natajaya dan Yudana (2013), yang menyatakan bahwa pemeliharaan peralatan disusun sesuai dengan perencanaan, proses dan hasil yang didapatkan, untuk pengadaan peralatan dapur praktik boga sudah oftimal, perlu mengadakan teknisi pemeliharaan peralatan.,dan dirancang untuk diadakan perawatan rutin, berkala, preventif dan darurat. Hasil temuan penelitian ini juga sesuai dengan penelitian Wiratma dan Subagia (2014), yang menyatakan bahwa pengelolaan laboratorium, secara umum dilakukan melalui rangkaian proses mulai dari aspek pengadaan, penggunaan dan pemeliharaan, dan aspek pemusnahan alat/bahan yang rusak.

Hasil temuan penelitian ini juga sesuai dengan penelitian Rosivia(2014), yang menyatakan bahwa dengan adanya pengelolaan yang baik, maka sarana prasarana akan dapat di gunakan dengan jangka waktu yang lebih lama, selain itu pengelolaan sarana dan prasarana bertujuan agar tercipta suatu kondisi yang kondusif, nyaman dan aman dalam proses pembelajaran. Proses pengelolaan sarana prasarana terdiri dari perencanaan, pengadaan, penyimpanan, inventaris, pemeliharaan, penghapusan dan pengawasan. Hasil temuan penelitian ini juga sesuai dengan penelitian Putranto (2016), yang menyatakan bahwa penunjang pembelajaran di laboratorium diantaranya adalah: pengadaan peralatan yang memadai, pemeliharaan peralatan yang maksimal, penggunaan maupun penyimpanan peralatan dan inventori peralatan laboratorium. Hasil temuan penelitian ini juga sesuai dengan penelitian Darmawan (2014), yang menyatakan bahwa pengelolaan sarana prasarana sekolah yang baik akan dapat meningkatkan kualitas pendidikan. Manajemen sarana prasarana pendidikan meliputi perencanaan, pengadaan, pemeliharaan, inventarisasi, dan penghapusan sarana prasarana di sekolah.

Dari hasil pernyataan nara sumber dan temuan penelitian terdahulu adanya pernyataan yang saling mendukung dan menguatkan dalam hal pemeliharaan alat diantaranya adanya kartu kontrol alat, adanya tempat penyimpanan alat yang sesuai dengan spesifikasinya, 
perawatan yang rutin dan berkala sehingga pemeliharaan alat dan bahan di bengkel Teknik Mekatronika perlu di laksanakan supaya alat yang digunakan dapat berlangsung lama dan tidak mudah rusak.

\section{PENUTUP}

Hasil penelitian dan pembahasan tentang “ Pengelolaan Bengkel Teknik Mekatronika SMK Negeri 2 Sukoharjo Tahun 2016" dapat disimpulkan bahwa pengelolaan meliputi :

1. Pengadaan alat dan bahan.

Berdasarkan hasil temuan penelitian menunjukkan bahwa proses pengadaan alat bahan di bengkel Teknik Mekatronika SMK Negeri 2 Sukoharjo sudah memenuhi aturan yang ada, dengan cara membeli alat dan bahan dimulai dari perencanaan yang berisi usulan pengajuan alat dan bahan yang diajukan oleh guru-guru di jurusan Teknik Mekatronika pada saat awal pembelajaran. Karena itu dilaksanakan analisis kebutuhan alat bahan dan seleksi peralatan, dengan mempertimbangkan pula skala prioritas dari alat dan bahan yang akan diadakan. Sumber dana untuk pengadaan alat dan bahan adalah dari pemerintah, baik pemerintah pusat maupun pemerintah daerah, sedang rekanan atau toko yang dijadikan acuan yaitu yang sudah mempunyai Nomor Pokok Wajib Pajak (NPWP) dan minimal ada 3 toko atau rekanan untuk dijadikan pertimbangan dan pembanding dalam pengadaan alat dan bahan.

2. Penggunaan alat dan bahan.

Berdasarkan hasil temuan penelitian menunjukkan bahwa penggunaan alat dan bahan di mulai dengan proses pemasangan kartu perawatan alat, setelah itu adanya pengajuan dari siswa yaitu kartu pinjam atau kartu bon alat dan bahan yang diketahui oleh kepala bengkel. Penggunaan alat harus sesuai dengan Standart Operational Procedur (SOP) dan semua alat harus diinventaris untuk mengetahui keadaan dan kegunaannya. Penggunaan alat dan bahan diatur oleh kepala paket keahlian sesuai jadwal pelajaran praktik/produktif, sehingga tidak berbenturan dengan pelajaran yang lain. Selanjutnya untuk inventarisasi alat dan bahan di bengkel Teknik Mekatronika ada petugas khusus di bawah kendali wakil kepala sekolah bidang sarana prasarana, namun dalam pelaksanaan di bengkel atau jurusan Teknik Mekatronika di bantu oleh kepala paket keahlian dan kepala bengkel. Dimana dalam kegiatan inventarisasi alat dan bahan yaitu secara berkala didata dan dicek ulang keberadaan serta kegunaan dari alat dan bahan tersebut, masih baik atau tidak sehingga semua alat dan bahan akan tercatat di buku inventaris jurusan maupun sekolah.

3. Pemeliharaan alat dan bahan.

Pemeliharaan alat dan bahan praktik di bengkel Tenik Mekatronika SMK Negeri 2 Sukoharjo, secara umum menjadi tanggung jawab kepala paket keahlian Teknik Mekatronika. Namun dalam pelaksanaannya dibantu oleh kepala bengkel juga siswa setelah praktik. Pemeliharaan dilakukan secara berkala dengan cara alat yang masih baru dipasangi kartu perawatan, sedang peralatan yang sudah digunakan diperiksa kartu perawatannya apakah sudah di isi belum mengenai kondisi alat baik itu sebelum dan sesudah praktik. Dari simpulan dan implikasi tersebut, maka peneliti dapat menyampaikan saran sebagai berikut : (1). Pihak Pengelola Bengkel Teknik Mekatronika. Guru, kepala bengkel dan kepala keahlian Teknik Mekatronika, dalam membuat RAB untuk pemenuhan kebutuhan alat dan bahan harus mengacu pada rasio jumlah siswa dengan jumlah alat dan bahan, harus sebanding sehingga 
pelaksanaan praktik akan lebih effektif. (2). Pihak Sekolah. Dalam pengajuan ruang untuk bengkel atau laboratorium kepada pemerintah, baik itu untuk ruang untuk guru praktik, ruang penyimpanan alat dan bahan praktik, maupun ruang untuk bengkel atau laboratorium praktik, harus melihat standar pemenuhan ruang. Karena untuk pemenuhan ruang praktik khususnya di Paket keahlian Teknik Mekatronika yang masih kurang. (3). Pihak Pemerintah. D a 1 a m hal ini baik Pemerintah Daerah maupun Pemerintah Pusat, dikarenakan SMK merupakan sekolah yang betul-betul di tunjuk menyiapkan tenaga kerja yang siap pakai, maka dalam pemenuhan sarana dan prasarana khususnya dalam pemenuhan ruang praktik serta alat dan bahan praktik lebih dioptimalkan.

\section{DAFTAR PUSTAKA}

Andriani, RF. Yudana, IM dan Natajaya, IN (2015), Identifikasi dan Analisis Kendala dalam Manajemen Pengelolaan Bengkel (Laboratorium) Multimedia di SMK Negeri 3 Singaraja. E-Journal Program Pasca Sarjana. Universitas Pendidikan Ganesha. Program Studi Administrasi Pendidikan. 6 (1) 1 - 9

Audu, R., Umar, I.Y., dan Idris, A.M (2013), Facilities provision and maintenance: Necessity for effective teaching and learning in technical vocational education. IOSR Journal of Research \& Methods in Education (IOSR-JRME). 3 (1)

Aurigemma, J., et.al. (2013), Turning experiments objects: the cognitive processes involved in the design of lab-on-a-chip device.

Darmastuti H dan Karwanto (2014), Manajemen sarana dan prasarana dalam upaya peningkatan kualitas pembelajaran pada jurusan teknik komputer dan informatika di SMK Negeri 2 Surabaya. Jurnal Inspirasi Manajemen Pendidikan. 3 (3) 9-20

Darmawan B (2014), Manajemen sarana dan prasarana dalam meningkatkan kualitas pendidikan. Jurnal pelopor pendidikan, manajemen sarana prasarana pendidikan. 6 (2) $93-102$

Gusbantoro, Hano dan Sutama (2015) Pengelolaan Bengkel Kerja Dalam Mempersiapkan Kemandirian Lulusan di SMK Satya Karya Karanganyar. Jurnal Pendidikan Vokasi, $V$ (1) $156-167$

Haron, H.N.B., Esmon, J.B., Yaacob, M.B, dan Abas, L.W.B. (2014), Security management in workshops of vocational studies in Malaysia. Research Journali's : Journal of Education, 2 (1)

Odden, E R and Wohlstetter (1995), Making School - Based Management Work. Educational leadership 52 (5) 32-36

Pahlevi R, Imron A, Kusumaningrum D E (2016), Manajemen saranan dan prasarana untuk meningkatkan mutu penbelajaran, Manajemen Pendidikan 25 (1) 88-94

Purwanto dan Sukardi,T (2015), Pengelolaan Bengkel Praktik SMK Teknik Pemesinan di Kabupaten Purworejo.Jurnal Teknologi dan Kejuruan 22 (3) 291-305

Putranto, (2016) Pengelolaan Dan Pengembangan Sarana Praktikum Laboratorium Dasar Instalasi Listrik Pada Prodi PTE Universitas Negeri Malang. TEKNO, Vol 25. (33-43)

Permendiknas No. 17 (2007), Standar Pengelolaan Pendidikan Bidang Sarana Prasarana. Jakarta 
PP No. 19 (2005),Standar Nasional Pendidikan, Jakarta : Departemen Pendidikan Nasional

Ramadina, S dan Hadi, S (2015), Pengembangan Sistem Informasi Manajemen Bengkel Kerja Sekolah Menengah Kejuruan. Jurnal Pendidikan Vokasi, V (1) 104-116

Ridhotullah, Subekti dan Jauhar, Mohammad. (2015). Pengantar Manajemen. Jakarta: Prestasi Pustakaraya.

Riswanti, HT, Samani R, dan Palupi AE. (2015), Pengaruh Pengelolaan Bengkel TKR Terhadap Pengetahuan, Ketrampilan Praktik dan Motivasi Belajar Siswa di SMK Negeri 1 Sambeng. Jurnal Pendidikan Vokasi: Teori dan Praktek. 3 (1) 11-20

Rufai, A., Musta'amal, A.H.B., Kamin, Y.B., dan Saud, M.S.B (2013), Provision of Workshop Tools and Equipment: Necessity for Technical Vocational Education Graduates Skills Acquisition. International Seminar on Quality an Affordc. 3 (1)

Rosivia (2014) Peningkatan Pengelolaan Sarana Prasarana Pendidikan Di Smp Negeri 10 Padang. Jurnal Administrasi Pendidikan, Bahana Manajemen Pendidikan. 2 ( 1) 661 $-831$

Satori, Djam'an dan Komariah, Aan. (2009). Metodologi Penelitian Kualitatif. Bandung : Alfabeta

Sudiarta N P, Natajaya N, Yudana I M (2013), Pengelolaan dapur praktik program studi manajemen tata boga STP Bali. e-Journal Program Pascasarjana Universitas Pendidikan Ganesha, Program Studi Administrasi Pendidikan, Volume 4

Widayati, Febri Setiyasih. (2013). Pengelolaan Laboratorium Ilmu Pengetahuan Alam Sekolah Standar Nasional (Studi Situs di SMP Negeri 1 Nogosari Boyolali). Surakarta : Tesis Universitas Muhammadiyah Surakarta

Wiratma G L dan Subagia W(2014) tentang Pengelolaan Laboratorium Kimia Pada Sma Negeri Di Kota Singaraja: (Acuan Pengembangan Model Panduan Pengelolaan Laboratorium Kimia Berbasis Kearifan Lokal Tri Sakti), Jurnal Pendidikan Indonesia, 3 (2) $425-436$. 